\title{
The Frequencies of Working with the Internet and Urban-Rural Wage Income Gap
}

\author{
Qinghua Wang \\ School of Economics, Jinan University, Guangzhou, China \\ Email: strive9109@126.com
}

How to cite this paper: Wang, Q.H. (2019) The Frequencies of Working with the Internet and Urban-Rural Wage Income Gap. Modern Economy, 10, 994-1017. https://doi.org/10.4236/me.2019.103067

Received: February 21, 2019

Accepted: March 23, 2019

Published: March 26, 2019

Copyright ( 2019 by author(s) and Scientific Research Publishing Inc. This work is licensed under the Creative Commons Attribution International License (CC BY 4.0).

http://creativecommons.org/licenses/by/4.0/

\begin{abstract}
Based on the China Family Panel Study (CFPS) 2014, this paper studied the relationship between the frequencies of working with the Internet and the wage income gap between urban and rural areas. The study found that the frequencies of working with the Internet has a significant effect on wage income through separate analyses of urban and rural areas; the frequencies of working with the Internet has no significant effect on the wage income gap between urban and rural areas; when using quantile regression, the frequencies of working with the Internet still has no significant impact on the wage income gap between urban and rural areas except at the $75^{\text {th }}$ quantile. These conclusions are different from the conclusions of direct comparison of regression coefficients. The FGLS method was used to solve the problem of heteroscedasticity in the urban subsample.
\end{abstract}

\section{Keywords}

Frequencies of Working with the Internet, Wage Gap, Coefficients Comparison, FGLS Method

\section{Introduction}

Reducing the income gap between urban and rural areas is the proper meaning of realizing the Chinese dream and the requirement for realizing the rural revitalization strategy. At present, China's urban and rural income gap is at a relatively high level. Although the Gini coefficient of urban and rural income has declined in recent years, it is still above the warning line of disparity between the rich and the poor. Wage income is the main source of income for urban and rural residents. Reducing the wage gap between urban and rural areas is of great significance for narrowing the income gap between urban and rural areas.

In recent years, the Chinese Internet, especially Internet finance and mobile 
Internet, has experienced rapid development. On January 31, 2018, the China Internet Network Information Center (CNNIC) released the "Statistically Report on the Development of China's Internet Network". As of December 2017, the number of Internet users in China reached 772 million, and the Internet penetration rate reached $55.8 \%$. The global average is 4.1 percentage points. The use of the Internet can bring great convenience to people, and the Internet has been fully integrated into various tasks.

How does the frequencies of people using the Internet at work affect wage income? And what effect will the frequencies of working with the Internet have on the wage income gap between urban and rural areas? How do the mechanism of action or mediators of these effects work? These issues are worth studying.

The innovations of this paper are as follows: Firstly, this paper studies the impact of the frequencies of using the Internet on the wage income gap between urban and rural areas. There is less research on the relationship between the frequencies of working with the Internet and the wage gap between urban and rural areas. The literature examines the relationship between the use of the Internet and personal income, and this study creates endogeneity problems in the cross-sectional data, biasing the estimated coefficients (Hamilton, 1997) [1]. Therefore, this paper studies the relationship between the use of the Internet and wage income from a new perspective. Secondly, when studying the impact of the frequencies of working with the Internet on urban and rural wage income, this paper divides the sample into two groups, urban and rural, and compares the coefficients of the core explanatory variables after regression to see if they are significantly different. Specifically, seemingly unrelated regression method and Fisher combinatorial test method are used to test the significance of the coefficients difference.

The rest of the paper is organized as follows: The second part is a literature review, which provides a brief review of relevant research at home and abroad. The third part is the data source and processing. The fourth part is empirical analysis. The fifth part is the analysis of robustness. The research conclusions and policy implications is the last part.

\section{Literature Review}

\subsection{Using the Internet to Work and the Urban-Rural Wage Income Gap}

The numbers of literature on the use of Internet and the gap between urban and rural wage income is not large at home. Based on the 2006 China Comprehensive Social Survey data, Meng Fanqiang (2012) [2] applied the Appleton decomposition method to analyze the causes of the urban-rural labor wage gap under the multiple segmentation of the labor market. Research shows that the wage gap between urban and rural labor in China's labor market is mainly due to the differences in individual characteristics of urban and rural labor, but there are also discrimination against rural labor. This kind of discrimination is mainly reflected 
in the different pay after the same work and unequal employment opportunities. Among them, unequal pay for equal work is the main form of household registration discrimination. Su, Heshmati and Almas (2013) [3] used the data from CHNS to study the determinants of personal income and he also studied the factors that influence the income gap between urban and rural areas. Studies have shown that the urban-rural income gap can be determined to a large extent by individual characteristics, especially by the level of education and the type of occupation. Xu Fenghui, Zhao Zhong (2014) [4] used the "Chinese employeesemployer matching data" surveyed by Renmin University of China to analyze the relationship between household registration system and corporate characteristics and wage gap. The results show that education is the most important variable affecting the wage income gap; the impact of gender on wage differences is still very large; non-agricultural hukou does have an impact on the wage gap, but the impact is not significant. Based on the CFPS 2010 baseline survey data, Liu Zhilong, Jin Wenjie (2015) [5] has shown that the use of computer networks has a significant premium effect on revenue. The longer the computer network is used, the higher the wage income, and the computer network has a stronger effect on the wage income of rural residents than the city. Chang Jinxiong, Zhao Haitao (2016) [6] analyzed the sources of discrimination against rural household labor in China's urban labor market based on CHNS data. The study found that the difference of educational return rate between urban household labor and rural household labor is the largest within the state-owned company; the wage premium of urban household labor in state-owned enterprises is significantly higher than that of rural household labor.

\subsection{The Relationship between Education Level and the Use of the Internet}

Nelson R R, Phelps E S (1966) [7] argue that human capital determines a country's ability to produce knowledge and that knowledge is necessary to digest new knowledge. The above literature indicates that the level of education affects Internet use, people with higher levels of education are more likely to use the Internet, and those with higher levels of education are more likely to use the Internet to work. Benhabib J, Spiegel M M (2005) [8] pointed out that education is considered as an important factor and prerequisite for the use of information technology because it provides the relevant skills needed to use information technology. Demoussis M, Giannakopoulos N (2006) [9] used a sample study from European countries to point out that education levels have a positive impact on the level of Internet application. Chinn M D, Fairlie R W (2007) [10] pointed out through research that the difference in education level is a relevant factor explaining the global digital divide. Goldfarb A, Prince J (2008) [11] have shown through empirical research that the higher the level of education, the greater the possibility of using the Internet. Wunnava P V, Leiter D B (2009) [12] used cross-sectional data from 100 countries and conclude that education has a positive effect on the spread of the Internet. 


\subsection{The Impact of Using Computers or the Internet on Wage Income}

There are a few studies on the impact of using computers or the Internet on wage income at home. Chen Yuyu, Wu Yuli (2008) [13] used the 2005 national household census data to study the rate of return on personal computer use. The study found that even if the individual's gender, age, education level, occupation, and wage stickiness were excluded, the return on wages of individuals's using computers was still as high as $20 \%$. The authors also studied the rate of return on the use of computers in different occupations, and the authors also added dummy variables in the profession and industry to control possible endogenous problems. The author also used the above salary income as a proxy variable for the incomprehensible variable such as individual intelligence level and work ability, and minimizes the impact of the "missing variable" and "endogenous problem" in the cross-sectional model. Bu Maoliang, Luo Huajiang (2011) [14] used the 2008 China Family Panel Survey (CFPS) data to study the impact of Internet usage on wage returns and explored the difference between urban and rural returns. The study found that after controlling for factors such as age, gender, education, ethnicity, and marriage, Internet use can bring in $60 \%$ of additional income, bringing about $78 \%$ of additional income in rural areas, and bringing about 38\% extra income in urban areas. Based on the 2004-2011 China Nutrition and Health Survey Data (CHNS), Li Yanan, Xie Qianyun (2017) [15] used the least squares method and the self-selection bias propensity score matching method to estimate the impact of Internet use on wage income. The results show that Internet use has a positive impact on individual wages, and this effect is greater for individuals with high school education. Mao Yufei, Zeng Xiangquan. (2018) [16] used Chinese Household Panel Survey data to examine the impact of Internet usage and preferences on gender wages. The results also found that the use of the Internet promoted wage growth.

There are many English literature on the impact of using computers or the Internet on wage income. Krueger A B (1993) [17] used the US Current Census Data (CPS) study in October 1984 and October 1989 in the United States to study and found that people who use computers at work get more income than those who do not use computers at work. And Krueger, through further research, concluded that the use of computers at work would be more pronounced among those with higher levels of education. Dinardo J E, Pischke J S (1997) [18] questioned the benefits of using computers. He believed that Krueger's results were inaccurate because Krueger's regression equation had problems with sample selection. Their research shows that the use of pencils at work can have a significant impact on an individual's wage income. However, the use of pencils is already very extensive, so it is unlikely to have an impact on wage income, which indicates the existence of sample selectivity bias. Hamilton B H (1997) [1] used HSB (High School and Beyond) data to analyze the impact of specific Internet skills on individual hourly wages, i.e. the impact of software skills and pro- 
gramming skills on individual hourly wages. The authors believe that if you use a computer at work as the explanatory variable, then this explanatory variable may reflect the characteristics of the company that hired the worker, so an accurate coefficient estimate cannot be obtained. Bell B D (2001) [19] analyzed the panel data in the UK and found that the use of computers and other skills have a significant relationship with personal income. The authors performed regression analysis with hourly wages as dependent variables, and the authors controlled a series of variables that may affect individual wage income to address possible endogenous problems, while also using panel data to control the existence of unobservable variables which will cause endogenous problem. Lee S H, Kim J (2004) [20] used the Current Population Survey (CPS) to study whether people who use the Internet at work get higher wages than those who do not use the Internet at work. The study found that in 1997, the use of the Internet at work could yield a significant wage premium, but this wage premium quickly disappeared, and it should now be considered that using the Internet at work does not generate additional income. Navarro L (2010) [21] studied the impact of Internet use on personal income in Latin American countries. The authors study the relationship between using the Internet and income at work and elsewhere. The results show that Internet usage has a significant impact on the income of both groups.

The existing literature mostly relies on the impact of whether to use the Internet on personal income and urban-rural income gap, there are few empirical studies on the impact of the frequencies of working with the Internet on personal income and the income gap of urban-rural wages. This paper examines the impact of the frequencies of working with the Internet on urban-rural wage income gap, which can enrich research in this area and provide empirical evidence for a comprehensive assessment of the effects of Internet use at work.

\section{The Data Source and Processing}

The data source is the 2014 China Family Panel Survey (CFPS) data from the China Social Science Research Center of Peking University. The survey is a nationwide follow-up survey that aims to reflect changes in China's society, economy, population, education, and health by tracking individual, family, and community samples. The nationwide survey of the project uses a stratified sampling approach involving 25 provinces, municipalities and autonomous regions except Tibet, Qinghai, Xinjiang, Ningxia, Inner Mongolia, Hainan, Hong Kong, Macau and Taiwan. Descriptive statistical analysis of variables is shown in Table 1.

\section{Empirical Analysis}

We first analyzed the frequencies of working with the Internet on the wage income in urban group and in rural group separately. The model is as follows:

$$
\text { Lnwage }_{i}=\alpha X_{i}+\beta \text { work }_{i}+\varepsilon_{i}
$$

Among them, Lnwage is the logarithm of the wage for the individual, $X$ is a 
Table 1. Variables and their description.

\begin{tabular}{|c|c|c|c|c|c|c|}
\hline variables & interpretation & Obs & Mean & $\begin{array}{l}\text { Standard } \\
\text { deviation }\end{array}$ & Min & $\operatorname{Max}$ \\
\hline Wage & Total wage income in 2014 & 3208 & 10.124 & 0.915 & 4.787 & 12.92 \\
\hline Work & $\begin{array}{c}\text { never }=1 \text {, once several months }=2 \text {, once a month }= \\
3 \text {, twice or three times a month }=4 \text {, once or twice a } \\
\text { week }=5 \text {, three to four times a week }=6 \text {, almost } \\
\text { every day }=7 \text {, Work }=1 \text { if frequencies } \geq 6 \text {, otherwise } \\
\text { Work }=0\end{array}$ & 3208 & 0.437 & 0.496 & 0 & 1 \\
\hline Urban & Dummy variable $($ urban $=1$, rural $=0$ ) & 3208 & 0.694 & 0.461 & 0 & 1 \\
\hline Male & Dummy variable $($ male $=1$, female $=0)$ & 3208 & 0.568 & 0.495 & 0 & 1 \\
\hline Age & range from 16 to 65 & 3208 & 32.367 & 9.564 & 16 & 62 \\
\hline Agesq/100 & Square of age divided by 100 & 3208 & 11.390 & 6.862 & 2.56 & 38.44 \\
\hline Married & Dummy variable (being married $=1$, else $=0$ ) & 3208 & 0.718 & 0.450 & 0 & 1 \\
\hline Illiterate/semi-literate & Illiterate/semi-literate & 3208 & 0.015 & 0.123 & 0 & 1 \\
\hline Primary school & Primary school & 3208 & 0.111 & 0.315 & 0 & 1 \\
\hline Junior high school & Junior high school & 3208 & 0.290 & 0.454 & 0 & 1 \\
\hline $\begin{array}{l}\text { High school/secondary } \\
\text { school/technical school/vocational } \\
\text { high school }\end{array}$ & $\begin{array}{l}\text { High school/secondary school/technical } \\
\text { school/vocational high school }\end{array}$ & 3208 & 0.276 & 0.447 & 0 & 1 \\
\hline College & College & 3208 & 0.177 & 0.382 & 0 & 1 \\
\hline Undergraduate & Undergraduate & 3208 & 0.130 & 0.337 & 0 & 1 \\
\hline Health & Dummy variable $($ healthy $=1$, else $=0)$ & 3208 & 0.869 & 0.337 & 0 & 1 \\
\hline Otherwork & Numbers of other work except for the main job & 3208 & 0.137 & 0.443 & 0 & 4 \\
\hline Promotion & $\begin{array}{l}\text { Whether got promoted in the job, dummy variable } \\
\qquad(\text { promoted }=1 \text {, else }=0)\end{array}$ & 3208 & 0.119 & 0.324 & 0 & 1 \\
\hline Computer & $\begin{array}{l}\text { Whether a computer needs to be used in the work, } \\
\text { dummy variable (yes }=1 \text {, else }=0 \text { ) }\end{array}$ & 3208 & 0.589 & 0.492 & 0 & 1 \\
\hline Scale & Number of employees & 3208 & 4.250 & 1.901 & 0 & 1 \\
\hline Cash & $\begin{array}{l}\text { Whether there is Cash benefits in the job, dummy } \\
\text { variable (yes }=1 \text {, else }=0 \text { ) }\end{array}$ & 3208 & 0.407 & 0.491 & 0 & 1 \\
\hline Welfare & $\begin{array}{l}\text { Whether there is Welfare benefits in the job, dummy } \\
\qquad \text { variable (yes }=1 \text {, else }=0 \text { ) }\end{array}$ & 3208 & 0.446 & 0.497 & 0 & 1 \\
\hline Intelligence & The level of intelligence & 3208 & 0.928 & 0.259 & 0 & 1 \\
\hline Contra & $\begin{array}{c}\text { Signing a contract or not, dummy variable (contra }= \\
1 \text { if signing a contract, contra }=0 \text { else })\end{array}$ & 3208 & 0.569 & 0.495 & 0 & 1 \\
\hline East & East region & 3208 & 0.426 & 0.495 & 0 & 1 \\
\hline Centre & Central region & 3208 & 0.247 & 0.431 & 0 & 1 \\
\hline West & West region & 3208 & 0.177 & 0.382 & 0 & 1 \\
\hline Northeast & Northeast region & 3208 & 0.150 & 0.357 & 0 & 1 \\
\hline Lpgdp & GDP per person in the local & 3208 & 10.828 & 0.415 & 10.181 & 11.549 \\
\hline Employer & Dummy variables of employer & 3208 & 3.504 & 1.184 & 1 & 8 \\
\hline Occupation & Dummy variables of occupation & 3208 & 8.384 & 5.561 & 1 & 19 \\
\hline
\end{tabular}


vector of control variables, work is the frequencies of working with the Internet. $\varepsilon$ is the error term, the subscript $i$ refers to the $i$ th observation.

From Table 2, it can be seen that the frequencies of working with the Internet has a positive and significant effect on the wage income of urban residents while other conditions remain unchanged. This effect is significant in model (1), model (2), and model (3). In the rural group, the frequencies of working with the Internet also has a significant effect on wage income. This effect is significant in model (4), model (5), and model (6). The control variables of model (1) and model (4) are factors that represent personal characteristics, including gender, education level, age, age squared divided by 100 , health status, marital status, and individual intelligence level. The purpose of intelligence is mainly to control the influence of the individual's ability on the individual's wage income, because the influence of the individual's educational level on the wage income may be related to the ability, that is, the person with higher education may own higher level of intelligence, this higher level of intelligence makes it easier for him to receive a higher level of education, on the other hand, the impact of the frequencies of working with the Internet may actually capture the effect of other variables such as the person's ability, so including the intelligence as the proxy variable of individual's ability is a good measure in order to get the accurate estimates.

Model (2) and Model (5) add some information about the work based on the original model, including whether they are promoted at work, whether they use computers at work, the size of the company, the physical benefits provided by the company, and the cash benefits provided by the company, whether the interviewee signed a labor contract. Model (3) and model (6) add other variables that affect individual wage income and some macro variables based on model (2) and model (5). These variables include the number of other jobs apart from the main job and the variables that represent the region where the labors live in. This paper divides the entire sample into four regions: the eastern, central, western, and northeastern regions, with the northeast as the baseline group. It also includes the per capita GDP variable of each province, which can control the impact of economic development levels in different regions on individual wage income. In all of the above models, the interactions of marital status and the gender are added, mainly considering that the impact of marital status on individual wage income is different between men and women.

In the urban group, there exists the discrimination against female while in the rural group there is no discrimination against female. This maybe because in the rural place, women's work are valued more than in the urban place. In Model (1) to Model (3), for the degree of education, when the control variables are gradually added, there is no significant difference in the wage income gap between the lower education level and the benchmark group in the urban group while those who has higher education level has a significant higher wage than the baseline group. In the rural group, when the control variables were gradually added, the academic qualification did not significantly promote the wage income. This 
Table 2. Separate analyses of the frequencies of working with the Internet.

\begin{tabular}{|c|c|c|c|c|c|c|}
\hline & \multicolumn{3}{|c|}{ Urban } & \multicolumn{3}{|c|}{ Rural } \\
\hline & (1) & (2) & (3) & $(4)$ & (5) & (6) \\
\hline \multirow[t]{2}{*}{ Frequencies } & $0.210^{* * *}$ & $0.108^{\star \star \star}$ & $0.099^{\star *}$ & $0.233^{* * *}$ & $0.152^{\star *}$ & $0.129^{*}$ \\
\hline & $(0.038)$ & $(0.040)$ & $(0.039)$ & $(0.071)$ & $(0.074)$ & $(0.073)$ \\
\hline \multirow[t]{2}{*}{ male } & $0.188^{\star *}$ & $0.177^{\star *}$ & $0.175^{\star *}$ & 0.114 & 0.113 & 0.085 \\
\hline & $(0.086)$ & $(0.083)$ & $(0.082)$ & $(0.106)$ & $(0.105)$ & $(0.106)$ \\
\hline \multirow[t]{2}{*}{ Primary school } & 0.132 & 0.171 & 0.238 & $-0.255^{*}$ & $-0.243^{*}$ & $-0.249^{*}$ \\
\hline & $(0.146)$ & $(0.150)$ & $(0.164)$ & $(0.136)$ & $(0.136)$ & $(0.133)$ \\
\hline \multirow[t]{2}{*}{ Junior high school } & 0.110 & 0.126 & 0.186 & $-0.265^{\star *}$ & $-0.281^{\star *}$ & $-0.293^{\star *}$ \\
\hline & $(0.137)$ & $(0.141)$ & $(0.157)$ & $(0.134)$ & $(0.134)$ & $(0.131)$ \\
\hline \multirow{3}{*}{$\begin{array}{l}\text { High school/seconda } \\
\text { school/technical } \\
\text { school/vocational high s }\end{array}$} & & & & & & \\
\hline & 0.190 & 0.149 & 0.233 & -0.229 & $-0.285^{\star *}$ & $-0.302^{\star *}$ \\
\hline & $(0.137)$ & $(0.141)$ & $(0.157)$ & $(0.142)$ & $(0.145)$ & $(0.142)$ \\
\hline \multirow[t]{2}{*}{ College } & $0.414^{* * *}$ & $0.331^{\star *}$ & $0.401^{\star *}$ & -0.105 & -0.181 & -0.203 \\
\hline & $(0.140)$ & $(0.144)$ & $(0.159)$ & $(0.154)$ & $(0.158)$ & $(0.154)$ \\
\hline \multirow[t]{2}{*}{ Undergraduate } & $0.650^{* * *}$ & $0.553^{\star \star *}$ & $0.611^{\star * *}$ & 0.073 & 0.038 & -0.002 \\
\hline & $(0.142)$ & $(0.147)$ & $(0.161)$ & $(0.171)$ & $(0.173)$ & $(0.171)$ \\
\hline \multirow[t]{2}{*}{ Age } & $0.108^{* * *}$ & $0.103^{* * *}$ & $0.107^{\star * *}$ & $0.129^{* * *}$ & $0.126^{\star * *}$ & $0.128^{\star * *}$ \\
\hline & $(0.016)$ & $(0.015)$ & $(0.015)$ & $(0.025)$ & $(0.025)$ & $(0.025)$ \\
\hline \multirow[t]{2}{*}{ Agesq } & $-0.124^{\star * *}$ & $-0.117^{\star \star \star}$ & $-0.122^{\star * *}$ & $-0.167^{\star \star *}$ & $-0.161^{\star * *}$ & $-0.168^{\star * *}$ \\
\hline & $(0.020)$ & $(0.020)$ & $(0.019)$ & $(0.035)$ & $(0.034)$ & $(0.034)$ \\
\hline \multirow[t]{2}{*}{ Health } & 0.073 & 0.065 & 0.074 & 0.020 & 0.042 & 0.055 \\
\hline & $(0.049)$ & $(0.047)$ & $(0.045)$ & $(0.089)$ & $(0.089)$ & $(0.087)$ \\
\hline \multirow[t]{2}{*}{ Married } & -0.113 & -0.090 & -0.091 & $-0.298^{\star * *}$ & $-0.262^{\star *}$ & $-0.294^{\star * *}$ \\
\hline & $(0.079)$ & $(0.077)$ & $(0.075)$ & $(0.111)$ & $(0.109)$ & $(0.110)$ \\
\hline \multirow[t]{2}{*}{ Intelligence } & -0.022 & -0.061 & -0.043 & 0.131 & 0.091 & 0.097 \\
\hline & $(0.072)$ & $(0.070)$ & $(0.067)$ & $(0.110)$ & $(0.110)$ & $(0.110)$ \\
\hline \multirow[t]{2}{*}{ Promotion } & & $0.176^{\star * *}$ & $0.186^{\star * *}$ & & $0.279^{* * *}$ & $0.296^{* * *}$ \\
\hline & & $(0.044)$ & $(0.042)$ & & $(0.082)$ & $(0.082)$ \\
\hline \multirow[t]{2}{*}{ Computer } & & $0.133^{* * *}$ & $0.121^{\star * *}$ & & 0.071 & 0.071 \\
\hline & & $(0.043)$ & $(0.042)$ & & $(0.072)$ & $(0.071)$ \\
\hline \multirow[t]{2}{*}{ Scale } & & $0.020^{*}$ & $0.021^{\star *}$ & & 0.028 & 0.026 \\
\hline & & $(0.010)$ & $(0.010)$ & & $(0.018)$ & $(0.018)$ \\
\hline \multirow[t]{2}{*}{ Welfare } & & $0.121^{\star * *}$ & $0.115^{\star * *}$ & & 0.070 & 0.064 \\
\hline & & $(0.036)$ & $(0.036)$ & & $(0.059)$ & $(0.058)$ \\
\hline Cash & & $0.211^{* * *}$ & $0.172^{* * *}$ & & $0.103^{*}$ & 0.091 \\
\hline
\end{tabular}




\begin{tabular}{|c|c|c|c|c|c|c|}
\hline \multicolumn{7}{|l|}{ Continued } \\
\hline & & $(0.036)$ & $(0.035)$ & & $(0.061)$ & $(0.061)$ \\
\hline \multirow[t]{2}{*}{ Contra } & & $0.191^{\star * *}$ & $0.121^{\star * *}$ & & 0.084 & 0.072 \\
\hline & & $(0.041)$ & $(0.041)$ & & $(0.065)$ & $(0.064)$ \\
\hline \multirow[t]{2}{*}{ Otherwork } & & & 0.052 & & & 0.026 \\
\hline & & & $(0.044)$ & & & $(0.075)$ \\
\hline \multirow[t]{2}{*}{ East } & & & $0.236^{\star * *}$ & & & 0.057 \\
\hline & & & $(0.054)$ & & & $(0.091)$ \\
\hline \multirow[t]{2}{*}{ Middle } & & & $0.108^{*}$ & & & 0.107 \\
\hline & & & $(0.060)$ & & & $(0.119)$ \\
\hline \multirow[t]{2}{*}{ West } & & & $0.185^{\star *}$ & & & 0.086 \\
\hline & & & $(0.073)$ & & & $(0.137)$ \\
\hline \multirow[t]{2}{*}{ Lpgdp } & & & $0.355^{\star * *}$ & & & $0.388^{\star * x}$ \\
\hline & & & $(0.073)$ & & & $(0.135)$ \\
\hline \multirow[t]{2}{*}{ Marriedmale } & $0.238^{\star *}$ & $0.235^{* * *}$ & $0.230^{* * *}$ & $0.555^{* * *}$ & $0.523^{* * *}$ & $0.563^{* * x}$ \\
\hline & $(0.093)$ & $(0.089)$ & $(0.088)$ & $(0.124)$ & $(0.123)$ & $(0.123)$ \\
\hline \multirow[t]{2}{*}{ Constant } & $7.587^{\star * *}$ & $7.347^{\star * *}$ & $3.172^{\star * *}$ & $7.672^{* * *}$ & $7.471^{* * *}$ & $3.230^{* *}$ \\
\hline & $(0.315)$ & $(0.313)$ & $(0.811)$ & $(0.410)$ & $(0.416)$ & $(1.484)$ \\
\hline Observations & 2227 & 2227 & 2227 & 981 & 981 & 981 \\
\hline $\mathrm{R}^{2}$ & 0.221 & 0.270 & 0.312 & 0.218 & 0.240 & 0.259 \\
\hline $\mathrm{P}>$ F-statistic & 0.000 & 0.000 & 0.000 & 0.000 & 0.000 & 0.000 \\
\hline
\end{tabular}

Robust standard errors in parentheses ${ }^{* *} \mathrm{p}<0.01,{ }^{* *} \mathrm{p}<0.05,{ }^{*} \mathrm{p}<0.1$.

shows that in the rural group, the role of education is not well reflected. It maybe because the economic level of rural areas is relatively backward. In the urban sample, people with college degree and above have no significant difference in wage income compared with the benchmark group, this result is valid in Model (4) to Model (6). For those whose education level is primary school, junior high school and high school/secondary school/technical school/vocational high school, the effect of these education level on the wage income are not different from the benchmark group when other control variables remain unchanged, this is consistent in Model (4) to Model (6). Age have a positive and significant effect on individual wage income in both urban and rural areas from Model (1) to Model (6). This may be because personal experience will increase as the age increases, which will help to increase the individual's wage income. In the urban group, the increase in age has a smaller effect on the individual wage income than the rural sample group. It may be because that the employers in the town own more skills as time went by. The factor of the square of the age divided by 100 is significantly negative in both the urban and rural sample groups. This shows that there is an inflexion point in the impact of age on individual wage income. After this threshold, age will have a negative effect on individual wage income. This thre- 
shold is 43.5 years in Model (1), 44.0 years in Model (2), 43.9 years in Model (3), and 38.6 years in Model (4), in Model (5) 39.1 years old, 38.1 years old in Model (6). This shows that the inflexion point of the effect of age on individual wage income in the urban sample is larger than that in the rural sample. Health status does not have a significant effect on wage income in all the models. This maybe because every person need to work hard in order to get more wage regardless of his or her health condition. In rural areas, marital status have a negative and significant impact on wage income while the coefficients are not significant in the urban area. The partial effect of wage on the variable Married is

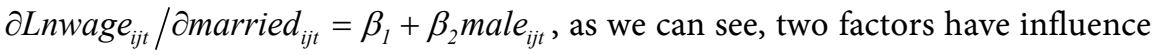
on the partial effects of Lnwage on Married, in the rural group, the coefficients of Married in is significantly negative, which indicates that the coefficient of $\beta_{1}$ is significantly negative, on the otherhand, the coefficient of Marriedmale is significantly positive and the absolute value is bigger, when we consider female, the second part of the partial effects is zero, so the total partial effects is significantly negative, which means that women get bad results when her marriage status is married and has a spouse. On the contrary, when we consider male, the second part of the partial effects is the coefficient of the interaction term, therefore, the total effects is significantly positive, so men can benefit from the marriage status which is married and having a spouse. The coefficients of Intelligence are not significant in all the models, this may be because that the abilities captured by the Intelligence are not important for deciding the amount of wage income.

After joining the second set of control variables, for promotion, whether in urban or rural areas, promotion will have a positive effect on the individual's wage income, this effect is consistent in Model (2), Model (3), Model (5) and Model (6). And the effects of promotion in rural areas is greater than that of urban areas. In the urban group, the need of using computers when working will have a significant effect on the individual's wage income, and this relationship is still significant after joining the third set of control variables. In the rural group, the coefficients of Computer have no significant effect on the individual's wage income in Model (5) and Model (6), which may be due to the low level of economic development in rural areas. In Model (2) and Model (3), the size of a company have a significant effect on an individual's wage income. However, in rural areas, the coefficients of Scale are not significant in Model (5) and Model (6). It maybe because of the low economic conditions in the rural areas. For physical benefits, in Model (2), they can significantly contribute to wage income in the urban group sample, and this relationship is significant after controlling the third set of control variables. But the coefficients of Welfare does not have a significant impact on the wage income in Model (5) and Model (6). This is probably because in rural groups, the level of physical benefits is low. Maybe the same reason applied to the cash benefits. In the urban sample, signing a labor contract has a significant positive impact on individual wage income, and this relationship is significant when joining the third set of control variables. In the 
rural sample, the signing of the labor contract is not significant. This maybe because people in the rural place didn't put enough emphasize on the contract, so they would not use the contract to protect their rights even though they have signed contracts. The F-statistics of all the Models are big enough so that the specifications of all the models are credible.

\subsection{The Effect of the Frequencies of Using the Internet on the Wage Gap between Urban and Rural Areas}

This paper uses the interaction term to test the effect of the frequencies of working with the on the wage income gap between urban and rural places. The model is as follows:

$$
\text { Lnwage }_{i j t}=\alpha X_{i j t}+\beta_{1} \text { Work }_{i j t}+\beta_{2} \text { Urban }_{i j t}+\beta_{3} \text { Inter }_{i j t}+\varepsilon_{i j t}
$$

Among them, Lnwage is the logarithm of the wage for the individual, $X$ is a vector of control variables, Work is the frequencies of working with the Internet, Urban indicates the place where the individuals live in, Inter is the interaction term of Work and Urban. $\varepsilon$ is the error term, the subscript $i, j, t$ refers to the ith observation, $t$ th employer, th occupation, respectively.

We can tell if the frequencies of working with the Internet has significant effect on the wage gap between urban and rural areas by looking at the symbol and the significance of the coefficient of the interaction term inter. The results are as follows:

In Table 3, the first model contains the first group of control variables, the coefficient of the Urban is not significant, the coefficient of variable Work is positive and significant, which means that the higher the frequencies of working with the Internet, the higher the individual wage income. The interaction term of the Urban and the Work is not significant, so that the frequencies of working with the Internet has no significant role on the wage income gap between urban and rural areas. As for other explanatory variables, male get more wage than female, the discrimination against female still exists. As for the education level, the benchmark group is the Illiterate/Semi-literate, we can see that the wage difference between those whose education level is primary school, junior high school, High school/secondary school/technical school/vocational high school and College and those of the benchmark is not significantly different. Those who has an education level of undergraduate has a significant higher wage income than the benchmark group. The coefficient of Agesq is negative and significant, this effect is significant at $1 \%$ level. This means that the effect of age on the wage income has an inflexion point, this point is 41.3 years old. As for the health condition, the healthy condition has a positive and significant effect on the individual wage income. When other explanatory variables and employer dummies and occupation dummies are included, the coefficients are still significant. This means that health is important for getting good wage income which is in accordance with our anticipation. As for the marital status, the coefficients are not significant in all the models. As for the Intelligence, the coefficient is positive but not significant, 
Table 3. The effect of the frequencies of working with the Internet on the wage gap.

\begin{tabular}{|c|c|c|c|c|c|}
\hline & (1) & (2) & (3) & (4) & (5) \\
\hline \multirow[t]{2}{*}{ Urban } & 0.048 & 0.028 & -0.022 & -0.020 & -0.010 \\
\hline & $(0.042)$ & $(0.040)$ & $(0.042)$ & $(0.043)$ & $(0.038)$ \\
\hline \multirow[t]{2}{*}{ Work } & $0.135^{* *}$ & 0.045 & 0.024 & 0.031 & 0.053 \\
\hline & $(0.063)$ & $(0.062)$ & $(0.055)$ & $(0.056)$ & $(0.057)$ \\
\hline \multirow[t]{2}{*}{ Inter } & 0.072 & 0.084 & 0.087 & 0.083 & 0.068 \\
\hline & $(0.066)$ & $(0.060)$ & $(0.056)$ & $(0.056)$ & $(0.060)$ \\
\hline \multirow[t]{2}{*}{ Male } & $0.194^{* * *}$ & $0.175^{\star * *}$ & $0.157^{* * *}$ & $0.155^{\star * \star}$ & $0.145^{\star * *}$ \\
\hline & $(0.054)$ & $(0.052)$ & $(0.052)$ & $(0.051)$ & $(0.049)$ \\
\hline \multirow[t]{2}{*}{ Primary school } & -0.104 & -0.096 & -0.080 & -0.084 & -0.069 \\
\hline & $(0.117)$ & $(0.103)$ & $(0.079)$ & $(0.077)$ & $(0.082)$ \\
\hline \multirow[t]{2}{*}{ Junior high school } & -0.113 & -0.136 & -0.130 & $-0.135^{*}$ & -0.124 \\
\hline & $(0.114)$ & $(0.100)$ & $(0.076)$ & $(0.075)$ & $(0.081)$ \\
\hline \multirow{3}{*}{$\begin{array}{l}\text { High school/secondary } \\
\text { school/technical } \\
\text { school/vocational high school }\end{array}$} & & & & & \\
\hline & -0.054 & -0.151 & -0.120 & -0.121 & -0.097 \\
\hline & $(0.109)$ & $(0.103)$ & $(0.078)$ & $(0.082)$ & $(0.093)$ \\
\hline \multirow[t]{2}{*}{ College } & 0.148 & 0.013 & 0.040 & 0.041 & 0.067 \\
\hline & $(0.105)$ & $(0.110)$ & $(0.090)$ & $(0.102)$ & $(0.115)$ \\
\hline \multirow[t]{2}{*}{ Undergraduate } & $0.347^{* *}$ & 0.207 & $0.239^{*}$ & 0.243 & $0.283^{\star}$ \\
\hline & $(0.131)$ & $(0.138)$ & $(0.118)$ & $(0.141)$ & $(0.156)$ \\
\hline \multirow[t]{2}{*}{ Age } & $0.119^{* * *}$ & $0.112^{\star * *}$ & $0.112^{* * *}$ & $0.112^{\star * *}$ & $0.107^{\star * *}$ \\
\hline & $(0.010)$ & $(0.009)$ & $(0.009)$ & $(0.009)$ & $(0.010)$ \\
\hline \multirow[t]{2}{*}{ Agesq/100 } & $-0.144^{* * *}$ & $-0.134^{\star * *}$ & $-0.134^{\star * *}$ & $-0.132^{\star * *}$ & $-0.125^{\star * *}$ \\
\hline & $(0.013)$ & $(0.012)$ & $(0.012)$ & $(0.013)$ & $(0.014)$ \\
\hline \multirow[t]{2}{*}{ Health } & $0.048^{*}$ & $0.060^{* *}$ & $0.072^{* * *}$ & $0.075^{\star * *}$ & $0.072^{\star * *}$ \\
\hline & $(0.023)$ & $(0.024)$ & $(0.022)$ & $(0.022)$ & $(0.022)$ \\
\hline \multirow[t]{2}{*}{ Married } & -0.149 & -0.112 & -0.126 & -0.127 & -0.130 \\
\hline & $(0.091)$ & $(0.082)$ & $(0.078)$ & $(0.078)$ & $(0.079)$ \\
\hline \multirow[t]{2}{*}{ Intelligence } & 0.020 & -0.023 & -0.007 & -0.001 & -0.001 \\
\hline & $(0.051)$ & $(0.051)$ & $(0.052)$ & $(0.054)$ & $(0.053)$ \\
\hline \multirow[t]{2}{*}{ Promotion } & & $0.206^{* * *}$ & $0.231^{* * *}$ & $0.232^{* * *}$ & $0.226^{* * *}$ \\
\hline & & $(0.043)$ & $(0.042)$ & $(0.044)$ & $(0.046)$ \\
\hline \multirow[t]{2}{*}{ Computer } & & $0.107^{* * *}$ & $0.103^{* * *}$ & $0.101^{* *}$ & $0.102^{* *}$ \\
\hline & & $(0.037)$ & $(0.036)$ & $(0.037)$ & $(0.037)$ \\
\hline \multirow[t]{2}{*}{ Scale } & & $0.037^{* * *}$ & $0.035^{\star * *}$ & $0.031^{\star * *}$ & $0.025^{* *}$ \\
\hline & & $(0.011)$ & $(0.011)$ & $(0.011)$ & $(0.010)$ \\
\hline Welfare & & $0.122^{* * *}$ & $0.107^{* * *}$ & $0.102^{\star * *}$ & $0.103^{* * *}$ \\
\hline
\end{tabular}




\section{Continued}

\begin{tabular}{|c|c|c|c|c|c|}
\hline & & $(0.032)$ & $(0.029)$ & $(0.030)$ & $(0.030)$ \\
\hline \multirow[t]{2}{*}{ Cash } & & $0.179^{* * *}$ & $0.139^{\star * *}$ & $0.139^{* * *}$ & $0.140^{\star * *}$ \\
\hline & & $(0.037)$ & $(0.027)$ & $(0.026)$ & $(0.025)$ \\
\hline \multirow[t]{2}{*}{ Contra } & & $0.156^{* * *}$ & $0.108^{* * *}$ & $0.100^{\star * *}$ & $0.109^{* * *}$ \\
\hline & & $(0.025)$ & $(0.027)$ & $(0.028)$ & $(0.031)$ \\
\hline \multirow[t]{2}{*}{ Otherwork } & & & 0.051 & 0.049 & 0.042 \\
\hline & & & $(0.039)$ & $(0.038)$ & $(0.035)$ \\
\hline \multirow[t]{2}{*}{ East } & & & $0.179^{* * *}$ & $0.177^{\star * *}$ & $0.183^{* * *}$ \\
\hline & & & $(0.046)$ & $(0.045)$ & $(0.045)$ \\
\hline \multirow[t]{2}{*}{ Centre } & & & $0.122^{\star}$ & $0.122^{*}$ & $0.125^{\star}$ \\
\hline & & & $(0.067)$ & $(0.066)$ & $(0.064)$ \\
\hline \multirow[t]{2}{*}{ West } & & & $0.181^{* * *}$ & $0.180^{* * *}$ & $0.184^{* * *}$ \\
\hline & & & $(0.050)$ & $(0.050)$ & $(0.051)$ \\
\hline \multirow[t]{2}{*}{ Lpgdp } & & & $0.387^{* * *}$ & $0.381^{\star * *}$ & $0.393^{* * *}$ \\
\hline & & & $(0.056)$ & $(0.059)$ & $(0.060)$ \\
\hline \multirow[t]{2}{*}{ Marriedmale } & $0.318^{* * *}$ & $0.303^{\star * *}$ & $0.324^{* * *}$ & $0.328^{\star * *}$ & $0.316^{* * *}$ \\
\hline & $(0.077)$ & $(0.079)$ & $(0.075)$ & $(0.077)$ & $(0.074)$ \\
\hline Employer dummies & No & No & No & No & Yes \\
\hline Occupation dummies & No & No & No & Yes & Yes \\
\hline \multirow[t]{2}{*}{ Constant } & $7.598^{* * *}$ & $7.400^{* * *}$ & $3.105^{* * *}$ & $3.310^{* * *}$ & $3.261^{* * *}$ \\
\hline & $(0.136)$ & $(0.156)$ & $(0.634)$ & $(0.675)$ & $(0.702)$ \\
\hline Observations & 3208 & 3208 & 3208 & 3208 & 3208 \\
\hline $\mathrm{R}^{2}$ & 0.203 & 0.253 & 0.288 & 0.289 & 0.296 \\
\hline
\end{tabular}

Robust standard errors in parentheses. ${ }^{* *} \mathrm{p}<0.01,{ }^{* *} \mathrm{p}<0.05,{ }^{\star} \mathrm{p}<0.1$.

after adding other explanatory variables, employer dummies and occupation dummies, the coefficients of Intelligence are still not significant.

Model (2) added another group of control variables based on the model (1). In this case, the interaction term of Urban and Work is still not significant. As for the new control variables, those who got promoted in their jobs will get more wage income, this symbol is in line with the anticipation. After adding more control variables and dummies, the coefficients of promotion is still positive and significant. As for the computer, for those people whose work need to use computers earn more wage than those whose work didn't, this maybe because for the work which need computers tend to be those that require more skills so that these work pay more. After adding more control variables and dummies, the coefficients of computers are still positive and significant. The coefficient of Scale is positive and significant in Model (2) Model (3) Model (4) and Model (5), this maybe because that bigger companies will have more scale effect. The coefficients of Welfare and Cash have positive and significant effects on the individ- 
ual wage income in Model (2) to Model (5), these symbols meet with the anticipation. As for the Contra, signing a contract is good for improving one's wage income, this maybe because that a contract will protect the labor's economic benefit, the symbol and significance of the Contra does not change after adding more control variables and dummies of employers and occupations.

Model (3) added the last group of control variables. The coefficient of Otherwork is positive but not significant. This maybe because that an individual has difficulties to do many jobs at the same time. As for the region, the benchmark group is northeast, we can see that the region of East, Centre, West has a positive and significant role on the wage income than the northeast. This maybe because that the economic situations of the other three regions are better than the benchmark group, so the people within these three regions can benefit from it. When it comes to Lpgdp, the coefficient is positive and significant and the symbol together with the significance don't change after more control variables and dummies of employers and occupations were included, this results are in line with the anticipation.

\subsection{Investigate the Impact of Urban and Rural Wage Income Disparities at Different Income Levels}

In order to test the effect of the frequencies of working with the Internet on the wage income gap at different wage distribution, quantile regressions are used to get the results. The results are as follows:

From the quantile regression results in Table 4, we found that the interaction of Urban and Work is not significant except in the $75^{\text {th }}$ quantile. The coefficient of Marriedmale is significant in all the models. With the coefficient of Married considered, it has been proven that for those who are married, male tend to get more wage than female. This maybe because married male have the responsibilities to earn more wage than female, who have more responsibilities to look after children. As for the male, the coefficient is positive and significant in almost all the models except in the $25^{\text {th }}$ quantile. This is the proof of the discrimination against female. For the education level, in the upper quantile, the tendency is that the higher the education, the higher the effects of education on the individual wage income. The coefficient of $A g e$ is positive and significant in all the models. And the coefficient of Agesq is negative and significant. This means that the effect of age on the wage income has an inflexion point. For the first model, the inflexion point is 42.3 years old; for the second model, the inflexion point is 41.0 years old; for the third model, the inflexion point is 41.6 years old; for the fourth model, the inflexion point is 46.0 years old; for the fifth model, the inflexion point is 51.9 years old; for the sixth model, the inflexion point is 42.8 years old. The coefficients of The variable Health is significant in $10^{\text {th }}$ and $75^{\text {th }}$ quantile, this means that the health condition is important for those whose wage income was in the lower end and upper end of the wage distribution. The coefficients of Intelligence was not significant in all the models. The coefficients of Promotion is positive and significant, which is in line with the anticipation. The 
Table 4. The effect of the frequencies of working with the Internet on the wage gap in different wage quantiles.

\begin{tabular}{|c|c|c|c|c|c|c|}
\hline & (1) & (2) & (3) & (4) & (5) & (6) \\
\hline & $10^{\text {th }}$ & $25^{\text {th }}$ & $50^{\text {th }}$ & $75^{\text {th }}$ & $90^{\text {th }}$ & OLS \\
\hline \multirow[t]{2}{*}{ Urban } & 0.006 & 0.033 & 0.035 & -0.029 & -0.044 & -0.010 \\
\hline & $(0.092)$ & $(0.055)$ & $(0.033)$ & $(0.031)$ & $(0.033)$ & $(0.043)$ \\
\hline \multirow[t]{2}{*}{ Work } & 0.095 & 0.113 & 0.026 & 0.003 & 0.064 & 0.053 \\
\hline & $(0.166)$ & $(0.074)$ & $(0.039)$ & $(0.038)$ & $(0.055)$ & $(0.061)$ \\
\hline \multirow[t]{2}{*}{ Inter } & 0.040 & -0.008 & 0.019 & $0.097^{\star *}$ & 0.082 & 0.068 \\
\hline & $(0.169)$ & $(0.078)$ & $(0.043)$ & $(0.042)$ & $(0.057)$ & $(0.065)$ \\
\hline \multirow[t]{2}{*}{ Marriedmale } & $0.215^{*}$ & $0.319^{* * *}$ & $0.280^{\star * *}$ & $0.230^{\star * *}$ & $0.162^{\star * *}$ & $0.316^{* * *}$ \\
\hline & $(0.130)$ & $(0.109)$ & $(0.060)$ & $(0.048)$ & $(0.044)$ & $(0.071)$ \\
\hline \multirow[t]{2}{*}{ Male } & $0.261^{* *}$ & 0.134 & $0.096^{*}$ & $0.130^{* * *}$ & $0.205^{\star * *}$ & $0.145^{* *}$ \\
\hline & $(0.120)$ & $(0.104)$ & $(0.056)$ & $(0.043)$ & $(0.038)$ & $(0.064)$ \\
\hline \multirow[t]{2}{*}{ Primary school } & -0.302 & -0.185 & 0.023 & $0.139^{*}$ & $0.152^{\star *}$ & -0.069 \\
\hline & $(0.491)$ & $(0.155)$ & $(0.079)$ & $(0.073)$ & $(0.067)$ & $(0.103)$ \\
\hline \multirow[t]{2}{*}{ Junior high school } & -0.302 & -0.227 & -0.040 & 0.103 & $0.167^{\star * *}$ & -0.124 \\
\hline & $(0.490)$ & $(0.151)$ & $(0.065)$ & $(0.073)$ & $(0.049)$ & $(0.099)$ \\
\hline \multirow{2}{*}{$\begin{array}{l}\text { High school/secondary } \\
\text { school/technical } \\
\text { school/vocational high } \\
\text { school }\end{array}$} & -0.265 & -0.197 & -0.012 & $0.134^{*}$ & $0.130^{* *}$ & -0.097 \\
\hline & $(0.491)$ & $(0.149)$ & $(0.067)$ & $(0.073)$ & $(0.052)$ & $(0.101)$ \\
\hline \multirow[t]{2}{*}{ College } & 0.031 & -0.006 & $0.156^{* *}$ & $0.274^{\star * *}$ & $0.229^{* * *}$ & 0.067 \\
\hline & $(0.492)$ & $(0.150)$ & $(0.069)$ & $(0.076)$ & $(0.052)$ & $(0.104)$ \\
\hline \multirow[t]{2}{*}{ Undergraduate } & 0.207 & 0.195 & $0.344^{* * *}$ & $0.450^{\star * *}$ & $0.372^{\star * *}$ & $0.283^{* * *}$ \\
\hline & $(0.493)$ & $(0.153)$ & $(0.071)$ & $(0.077)$ & $(0.057)$ & $(0.107)$ \\
\hline \multirow[t]{2}{*}{ Age } & $0.170^{\star * *}$ & $0.142^{\star * *}$ & $0.084^{* * *}$ & $0.057^{\star * *}$ & $0.056^{* * *}$ & $0.107^{\star * *}$ \\
\hline & $(0.018)$ & $(0.016)$ & $(0.010)$ & $(0.009)$ & $(0.009)$ & $(0.013)$ \\
\hline \multirow[t]{2}{*}{ Agesq/100 } & $-0.201^{\star * *}$ & $-0.173^{\star * *}$ & $-0.101^{\star * \star}$ & $-0.062^{* * *}$ & $-0.054^{* * *}$ & $-0.125^{\star * *}$ \\
\hline & $(0.022)$ & $(0.021)$ & $(0.014)$ & $(0.013)$ & $(0.012)$ & $(0.016)$ \\
\hline \multirow[t]{2}{*}{ Health } & $0.107^{* *}$ & 0.034 & 0.017 & $0.076^{\star * *}$ & 0.038 & $0.072^{*}$ \\
\hline & $(0.050)$ & $(0.054)$ & $(0.024)$ & $(0.026)$ & $(0.034)$ & $(0.040)$ \\
\hline \multirow[t]{2}{*}{ Married } & 0.124 & -0.065 & $-0.122^{\star *}$ & $-0.169^{* * *}$ & $-0.154^{* * *}$ & $-0.130^{* *}$ \\
\hline & $(0.106)$ & $(0.083)$ & $(0.053)$ & $(0.041)$ & $(0.035)$ & $(0.061)$ \\
\hline \multirow[t]{2}{*}{ Intelligence } & 0.089 & -0.051 & -0.011 & -0.011 & -0.008 & -0.001 \\
\hline & $(0.175)$ & $(0.089)$ & $(0.035)$ & $(0.022)$ & $(0.054)$ & $(0.058)$ \\
\hline \multirow[t]{2}{*}{ Promotion } & $0.188^{\star * *}$ & $0.197^{\star * *}$ & $0.168^{\star * *}$ & $0.126^{\star * *}$ & $0.154^{* * *}$ & $0.226^{* * *}$ \\
\hline & $(0.058)$ & $(0.049)$ & $(0.024)$ & $(0.030)$ & $(0.039)$ & $(0.038)$ \\
\hline \multirow[t]{2}{*}{ Computer } & $0.139^{* * *}$ & $0.107^{* *}$ & $0.123^{* * *}$ & $0.090^{* * *}$ & $0.098^{\star * *}$ & $0.102^{\star * *}$ \\
\hline & $(0.054)$ & $(0.043)$ & $(0.028)$ & $(0.025)$ & $(0.030)$ & $(0.037)$ \\
\hline
\end{tabular}




\section{Continued}

\begin{tabular}{|c|c|c|c|c|c|c|}
\hline \multirow[t]{2}{*}{ Scale } & $0.027^{* *}$ & $0.032^{\star * *}$ & $0.033^{* * *}$ & $0.022^{* * *}$ & $0.022^{\star * *}$ & $0.025^{\star * *}$ \\
\hline & $(0.012)$ & $(0.009)$ & $(0.006)$ & $(0.006)$ & $(0.007)$ & $(0.009)$ \\
\hline \multirow[t]{2}{*}{ Welfare } & $0.093^{*}$ & $0.103^{\star * *}$ & $0.099^{* * *}$ & $0.090^{* * *}$ & $0.076^{\star * *}$ & $0.103^{* * *}$ \\
\hline & $(0.047)$ & $(0.032)$ & $(0.022)$ & $(0.020)$ & $(0.022)$ & $(0.030)$ \\
\hline \multirow[t]{2}{*}{ Cash } & $0.135^{\star * *}$ & $0.180^{\star * *}$ & $0.128^{\star * *}$ & $0.133^{* * *}$ & $0.117^{* * *}$ & $0.140^{* * *}$ \\
\hline & $(0.047)$ & $(0.032)$ & $(0.022)$ & $(0.021)$ & $(0.022)$ & $(0.030)$ \\
\hline \multirow[t]{2}{*}{ Contra } & $0.231^{\star * *}$ & $0.125^{\star * *}$ & 0.041 & -0.005 & -0.027 & $0.109^{* * *}$ \\
\hline & $(0.064)$ & $(0.048)$ & $(0.028)$ & $(0.024)$ & $(0.026)$ & $(0.034)$ \\
\hline \multirow[t]{2}{*}{ Otherwork } & 0.066 & 0.017 & -0.004 & 0.028 & $0.122^{\star * *}$ & 0.042 \\
\hline & $(0.093)$ & $(0.061)$ & $(0.035)$ & $(0.043)$ & $(0.042)$ & $(0.038)$ \\
\hline \multirow[t]{2}{*}{ East } & $0.221^{\star * *}$ & $0.263^{\star * *}$ & $0.144^{\star * *}$ & $0.130^{* * *}$ & $0.187^{\star * *}$ & $0.183^{* * *}$ \\
\hline & $(0.062)$ & $(0.048)$ & $(0.037)$ & $(0.030)$ & $(0.027)$ & $(0.046)$ \\
\hline \multirow[t]{2}{*}{ Centre } & 0.065 & $0.092^{*}$ & $0.100^{* *}$ & $0.093^{* * *}$ & $0.205^{\star * *}$ & $0.125^{\star *}$ \\
\hline & $(0.075)$ & $(0.050)$ & $(0.041)$ & $(0.032)$ & $(0.031)$ & $(0.053)$ \\
\hline \multirow[t]{2}{*}{ West } & 0.101 & $0.167^{\star *}$ & $0.165^{\star * *}$ & $0.117^{\star * *}$ & $0.255^{\star * *}$ & $0.184^{* * *}$ \\
\hline & $(0.096)$ & $(0.071)$ & $(0.048)$ & $(0.039)$ & $(0.047)$ & $(0.063)$ \\
\hline \multirow[t]{2}{*}{ Lpgdp } & $0.357^{* * *}$ & $0.327^{* * *}$ & $0.347^{* * *}$ & $0.356^{* * *}$ & $0.460^{* * *}$ & $0.393^{* * *}$ \\
\hline & $(0.092)$ & $(0.065)$ & $(0.039)$ & $(0.044)$ & $(0.044)$ & $(0.064)$ \\
\hline Employer dummies & Yes & Yes & Yes & Yes & Yes & Yes \\
\hline Occupation dummies & Yes & Yes & Yes & Yes & Yes & Yes \\
\hline \multirow[t]{2}{*}{ Constant } & 1.466 & $3.012^{\star * \star}$ & $4.420^{\star * *}$ & $4.993^{\star * *}$ & $3.961^{* * *}$ & $3.261^{* * *}$ \\
\hline & $(1.181)$ & $(0.779)$ & $(0.473)$ & $(0.510)$ & $(0.489)$ & $(0.706)$ \\
\hline Observations & 3,208 & 3,208 & 3,208 & 3,208 & 3,208 & 3,208 \\
\hline $\mathrm{R}^{2}$ & 0.218 & 0.198 & 0.163 & 0.172 & 0.198 & 0.296 \\
\hline
\end{tabular}

Robust standard errors in parentheses. ${ }^{* *} \mathrm{p}<0.01,{ }^{* *} \mathrm{p}<0.05,{ }^{*} \mathrm{p}<0.1$

coefficient of Computer is positive and significant in all the models. As for the scale, the coefficients are positive and significant in all models. The coefficients of Welfare and Cash have positive and significant effects on the individual wage income in all the models, which is in line with anticipation. The coefficients of Contra is positive and significant in $10^{\text {th }}$ and $25^{\text {th }}$ quantile. This maybe because that people whose wage income located in the low end of the distribution can get more benefits from the contracts while for the people whose wage income is in the high end of the wage distribution, the effect of the contracts are not big enough. The coefficients of Otherwork are positive and significant in $90^{\text {th }}$ quantile, this maybe because that for those whose wage are in the high end own more abilities which enable them to do more than one job, so they can get more wage income. As for the region, the coefficients of East are positive and significant in all the models, this maybe because that the economy in the east is good than in the northeast; the coefficients of Centre are positive in all quantiles except the $10^{\text {th }}$ quantile, which maybe because that in the middle and upper end of the wage 
distribution, the economy situation in the center part of China is better than in the northeast. The same situation applied to the west region. As for the Lpgdp, the coefficients are positive and significant in all the models, this means that if the GDP per person is high, every person can get benefits from it. The employer dummies and the occupation dummies are controlled in all of the models.

\section{Tests for Heteroscedasticity and Correlation}

In cross-section data, the problem of heteroscedasticity is not often met with. In order to test if this problem exists. This paper use the White's test to realize the goal. This method was put up by White (1980). The White's test is a kind of LM (Lagrange Multiplier) test which doesn't need to know if the problem of heteroscedasticity exists (Tables $5-10$ ).

Table 5. Test of heteroscedasticity of Model (1).

\begin{tabular}{ccc}
\hline Null hypothesis & Test results & Explanation of Model (1) \\
\hline Homoscedasticity & $\mathrm{chi}^{2}(442)=442.83$ & Can not reject the null hypothesis \\
& Prob $>\mathrm{chi}^{2}=0.4799$ & \\
\hline
\end{tabular}

Table 6. Test of heteroscedasticity of Model (2).

\begin{tabular}{ccc}
\hline Null hypothesis & Test results & Explanation of Model (2) \\
\hline Homoscedasticity & $\operatorname{chi}^{2}(665)=732.38$ & Reject the null hypothesis, hete- \\
& Prob $>\mathrm{chi}^{2}=0.0354$ & roscedasticity exists. \\
\hline
\end{tabular}

Table 7. Test of heteroscedasticity of Model (3).

\begin{tabular}{ccc}
\hline Null hypothesis & Test results & Explanation of Model (3) \\
\hline Homoscedasticity & $\operatorname{chi}^{2}(874)=1002.95$ & Reject the null hypothesis, hete- \\
Prob $>\mathrm{chi}^{2}=0.0015$ & roscedasticity exists.
\end{tabular}

Table 8. Test of heteroscedasticity of Model (4).

\begin{tabular}{ccc}
\hline Null hypothesis & Test results & Explanation of Model (4) \\
\hline Homoscedasticity & $\mathrm{chi}^{2}(375)=364.88$ & Can not reject the null hypothesis \\
& Prob $>\mathrm{chi}^{2}=0.6362$ & \\
\hline
\end{tabular}

Table 9. Test of heteroscedasticity of Model (5).

\begin{tabular}{ccc}
\hline Null hypothesis & Test results & Explanation of Model (5) \\
\hline Homoscedasticity & $\operatorname{chi}^{2}(565)=530.89$ & Can not reject the null hypothesis \\
& Prob $>\mathrm{chi}^{2}=0.8452$ & \\
\hline
\end{tabular}

Table 10. Test of heteroscedasticity of Model (6).

\begin{tabular}{ccc}
\hline Null hypothesis & Test results & Explanation of Model (6) \\
\hline Homoscedasticity & chi2 $(730)=741.79$ & Can not reject the null hypothesis \\
& Prob $>\mathrm{chi}^{2}=0.3728$ & \\
\hline
\end{tabular}


For Model (2), the White's test results are as follows:

For Model (3), the White's test results are as follows:

For Model (4), the White's test results are as follows:

For Model (5), the White's test results are as follows:

For Model (6), the White's test results are as follows:

Through the White's test, we can see that in the urban sample, problems of heteroscedasticity exist. Therefore, this paper used the FGLS which means Feasible General Least Square to obtain the accurate estimates. After tests, heteroscedasticity exists in the urban sample, so this paper used the FGLS with the urban sample only. The results are shown in Table 11:

Table 11. The results using the method of FGLS in urban subsample.

\begin{tabular}{|c|c|c|c|}
\hline & \multicolumn{3}{|c|}{ Urban } \\
\hline & (1) & (2) & (3) \\
\hline \multirow[t]{2}{*}{ Frequencies } & $0.211^{\star * *}$ & $0.182^{\star * *}$ & $0.093^{* * *}$ \\
\hline & $(0.033)$ & $(0.054)$ & $(0.025)$ \\
\hline \multirow[t]{2}{*}{ male } & $0.203^{* *}$ & 0.060 & $0.172^{*}$ \\
\hline & $(0.075)$ & $(0.073)$ & $(0.089)$ \\
\hline \multirow[t]{2}{*}{ Primary school } & 0.105 & -0.070 & $0.244^{\star}$ \\
\hline & $(0.097)$ & $(0.199)$ & $(0.127)$ \\
\hline \multirow[t]{2}{*}{ Junior high school } & 0.101 & -0.122 & $0.230^{*}$ \\
\hline & $(0.127)$ & $(0.164)$ & $(0.126)$ \\
\hline \multirow{2}{*}{$\begin{array}{l}\text { High school/secondary school/technical } \\
\text { school/vocational high school }\end{array}$} & 0.156 & -0.163 & $0.263^{*}$ \\
\hline & $(0.117)$ & $(0.212)$ & $(0.132)$ \\
\hline \multirow[t]{2}{*}{ College } & $0.368^{\star * *}$ & -0.059 & $0.436^{\star * *}$ \\
\hline & $(0.113)$ & $(0.197)$ & $(0.147)$ \\
\hline \multirow[t]{2}{*}{ Undergraduate } & $0.607^{* * *}$ & 0.216 & $0.624^{* * *}$ \\
\hline & $(0.153)$ & $(0.205)$ & $(0.185)$ \\
\hline \multirow[t]{2}{*}{ Age } & $0.091^{* * *}$ & $0.127^{\star * *}$ & $0.077^{\star * *}$ \\
\hline & $(0.012)$ & $(0.027)$ & $(0.011)$ \\
\hline \multirow[t]{2}{*}{ Agesq/100 } & $-0.104^{* * *}$ & $-0.165^{\star * *}$ & $-0.085^{\star * *}$ \\
\hline & $(0.015)$ & $(0.040)$ & $(0.013)$ \\
\hline \multirow[t]{2}{*}{ Health } & $0.060^{* *}$ & 0.047 & $0.060^{* *}$ \\
\hline & $(0.028)$ & $(0.103)$ & $(0.029)$ \\
\hline \multirow[t]{2}{*}{ Married } & -0.114 & $-0.212^{\star \star}$ & -0.057 \\
\hline & $(0.075)$ & $(0.076)$ & $(0.053)$ \\
\hline \multirow[t]{2}{*}{ Intelligence } & -0.001 & 0.155 & -0.039 \\
\hline & $(0.052)$ & $(0.133)$ & $(0.057)$ \\
\hline Promotion & & $0.188^{\star * *}$ & $0.141^{\star * *}$ \\
\hline
\end{tabular}




\section{Continued}

\begin{tabular}{|c|c|c|c|}
\hline & & $(0.062)$ & $(0.041)$ \\
\hline \multirow[t]{2}{*}{ Computer } & & 0.034 & $0.136^{* * *}$ \\
\hline & & $(0.050)$ & $(0.034)$ \\
\hline \multirow[t]{2}{*}{ Scale } & & $0.034^{* *}$ & $0.025^{* *}$ \\
\hline & & $(0.013)$ & $(0.012)$ \\
\hline \multirow[t]{2}{*}{ Welfare } & & 0.058 & $0.116^{* * *}$ \\
\hline & & $(0.041)$ & $(0.032)$ \\
\hline \multirow[t]{2}{*}{ Cash } & & $0.096^{*}$ & $0.145^{* * *}$ \\
\hline & & $(0.050)$ & $(0.038)$ \\
\hline \multirow[t]{2}{*}{ Contra } & & 0.053 & $0.103^{*}$ \\
\hline & & $(0.063)$ & $(0.055)$ \\
\hline \multirow[t]{2}{*}{ Otherwork } & & & 0.024 \\
\hline & & & $(0.037)$ \\
\hline \multirow[t]{2}{*}{ East } & & & $0.209^{* * *}$ \\
\hline & & & $(0.047)$ \\
\hline \multirow[t]{2}{*}{ Centre } & & & $0.131^{* * *}$ \\
\hline & & & $(0.043)$ \\
\hline \multirow[t]{2}{*}{ West } & & & $0.168^{* * *}$ \\
\hline & & & $(0.043)$ \\
\hline \multirow[t]{2}{*}{ Lpgdp } & & & $0.409^{* * *}$ \\
\hline & & & $(0.064)$ \\
\hline \multirow[t]{2}{*}{ Marriedmale } & $0.180^{* *}$ & $0.471^{\star * *}$ & $0.170^{* *}$ \\
\hline & $(0.064)$ & $(0.099)$ & $(0.069)$ \\
\hline Emploer dummies & Yes & Yes & Yes \\
\hline Occupation dummies & Yes & Yes & Yes \\
\hline \multirow[t]{2}{*}{ Constant } & $7.655^{\star * *}$ & $7.277^{\star * *}$ & $3.065^{* * *}$ \\
\hline & $(0.284)$ & $(0.360)$ & $(0.729)$ \\
\hline Observations & 2227 & 981 & 2227 \\
\hline $\mathrm{R}^{2}$ & 0.207 & 0.275 & 0.319 \\
\hline
\end{tabular}

Robust standard errors in parentheses. ${ }^{* * *} \mathrm{p}<0.01,{ }^{* *} \mathrm{p}<0.05,{ }^{*} \mathrm{p}<0.1$.

From Table 11, we can see that the frequencies of working with the Internet still has a positive and significant effect on the individual wage income. Most explanatory variables have the similar results as above. The individual correlation within occupations was considered when calculating the standard errors. What's more, the Employer dummies and the Occupation dummies were included.

\section{Robustness Check}

In order to verify whether the regression results obtained above are robust, the 
regression results are analyzed for robustness.

\subsection{Seemingly Unrelated Regression Model Test}

This paper uses the method proposed by Lian Yujun, Liao Junping (2017) [22] to test the difference between groups after group regression. That is, the regression results were tested for robustness using a seemingly unrelated regression model. A seemingly uncorrelated model is two models that seem to have no relationship on the surface but are essentially related. The relationship here is to assume that the error items of the urban group and the rural group are related to each other. The models of the urban group and the rural group are as follows:

$$
\begin{gathered}
\text { Lnwage }_{1 i}=\alpha_{1} X_{1 i}+\beta_{1} \text { work }_{1 i}+\varepsilon_{1 i}, i=1,2, \cdots, \mathrm{N} 1 \\
\text { Lnwage }_{2 j}=\alpha_{2} X_{2 j}+\beta_{2} \text { work }_{2 j}+\varepsilon_{2 j}, j=1,2, \cdots, \mathrm{N} 2
\end{gathered}
$$

Although the urban and rural areas are different, there are many similarities in terms of the social and legal environment and the government's policies. The error term between the two may be related, that is, corr $\left(\varepsilon_{1 i}, \varepsilon_{2 j}\right) \neq 0$. At this point, after performing the SUR estimation on the two sample groups, the coefficients difference between the two groups is tested. The regression results are shown in Table 12.

As can be seen from Table 12, the effect of the frequencies of working with the Internet on individual wage income is not significantly different between urban and rural areas. Therefore, the frequencies of working with the Internet does not have a significant impact on the urban-rural wage income gap, which verifies the conclusions reached in this paper. In the above regression equations, both the urban and rural models control the control variables, employer fixed effects, occupational fixed effects.

\subsection{Fisher Combination Test}

This paper also uses another method proposed by Lian Yujun, Liao Junping.

\begin{tabular}{|c|c|c|}
\hline & \multicolumn{2}{|c|}{ Year 2014} \\
\hline & urban & rural \\
\hline \multirow[t]{2}{*}{ Frequencies } & $0.099^{\star *}$ & $0.129^{*}$ \\
\hline & $(0.040)$ & $(0.072)$ \\
\hline $\begin{array}{l}\text { The difference of the coefficients of the frequencies } \\
\text { of working with the Internet }\end{array}$ & \multicolumn{2}{|c|}{-0.030} \\
\hline Control Variables & Yes & Yes \\
\hline Employer dummies & Yes & Yes \\
\hline Occupation dummies & Yes & Yes \\
\hline $\mathrm{N}$ & 2227 & 981 \\
\hline $\mathrm{R}^{2}$ & 0.312 & 0.259 \\
\hline The P-value of the difference & & \\
\hline
\end{tabular}

Table 12. SUR test for the significance of the coefficients difference.

Robust standard errors in parentheses. ${ }^{* *} \mathrm{p}<0.01,{ }^{* *} \mathrm{p}<0.05,{ }^{*} \mathrm{p}<0.1$. 
(2017) [22] to test the significance of the coefficients difference between groups after group regression, that is, to use Fisher's combinatorial test to test whether the differences between the two regression coefficients are significant. This method also divides the sample into urban group and rural group, with model settings such as model (3) and model (4). The coefficients of the frequencies of working with the Internet are $\beta_{1}$ and $\beta_{2}$, respectively. Then the coefficient difference between the two is $\mathrm{d}=\beta_{1}-\beta_{2}$, and the original hypothesis of the test is: $\mathrm{H}_{0}: \mathrm{d}=0, \mathrm{~d}$ is a statistic. If the distribution characteristics are known in advance, we can judge the probability that we observe $d=\beta_{1}-\beta_{2}$ by analyzing the position of $\mathrm{d}$ in its distribution. If the probability is small, it indicates that $\mathrm{H}_{0}: \mathrm{d}=0$ is a small probability event, and the null hypothesis should be rejected at this time, otherwise the null hypothesis cannot be rejected. However, in the actual application process, we do not know the distribution characteristics of d. At this point, the existing samples can be resampled to obtain an empirical sample, and the empirical sample is used to construct a coefficient difference statistic $d$ between the groups. The empirical p-value is obtained by the distribution of $\mathrm{d}$. The regression results are shown in Table 13.

As can be seen from Table 13, the effect of the frequencies of working with the Internet on individual wage income is not significantly different between urban and rural areas. Therefore, the frequencies of working with the Internet do not have a significant impact on the urban-rural wage income gap. Besides, the regressions above controlled the control variables, employer fixed effects, occupational fixed effects. Therefore, the conclusions reached in this paper are robust.

\section{Conclusions and Revelations}

Through the analysis of the 2014 China Family Panel Survey (CFPS) data, this paper finds that the frequencies of working with the Internet has a significant effect on the individual's wage income. When adding more control variables, this kind of relationship is still established. Further research finds that the frequencies of working with the Internet do not have a significant impact on the wage income gap between urban and rural areas. This relationship is still valid when more control variables are added and a series of dummy variables are added.

Table 13. Fisher combination test for the significance of the coefficients difference.

\begin{tabular}{|c|c|c|}
\hline & \multicolumn{2}{|c|}{ Year 2014} \\
\hline & Urban & Rural \\
\hline Frequencies & $\begin{array}{c}0.099^{\star *} \\
(2.55)\end{array}$ & $\begin{array}{c}0.129^{x} \\
(1.77)\end{array}$ \\
\hline The differences of the frequencies & & \\
\hline $\mathrm{N}$ & 2,227 & 981 \\
\hline $\mathrm{R}^{2}$ & 0.312 & 0.259 \\
\hline The P-value of the differences & & \\
\hline
\end{tabular}

Robust standard errors in parentheses. ${ }^{* *} \mathrm{p}<0.01,{ }^{* *} \mathrm{p}<0.05,{ }^{*} \mathrm{p}<0.1$. 
When studying the impact of the frequencies of working with the Internet on the wage gap between urban and rural wages at different quantile levels, this paper finds that the frequencies of working with the Internet has no significant effect on the wage gap except for the $75^{\text {th }}$ quantile.

In the urban subsample, heteroscedasticity was discovered, so the FGLS method was used to get the accurate estimates. The results show that the frequencies of working with the Internet still have positive and significant effect on the individual wage income.

In the robustness test, it is tested whether the difference between the two regression coefficients is significant. The results show that the difference between the two regression coefficients is not significant, which is different from the previous direct comparison of regression coefficients. This shows that maybe it is not a good idea to reach a conclusion by simply comparing the coefficients of the two sets of regressions.

The impact of the frequencies of working with the Internet is not significantly different between urban and rural areas. Therefore, residents in rural areas should be encouraged to use the Internet at work, which can increase the wage income of rural residents and can curb the widening income gap between urban and rural wages. In order to make it convenient for rural residents to use the Internet when working, the government should take more measures to improve the penetration of the Internet and some lessons should be given to those who do not know how to use the Internet.

This paper has only studied the cross-sectional data which may be susceptible to unobservable predictors that are correlated with the core explanatory variable, and these unobserved predictors are also rewarded in the labor market. In this case, the accurate estimates could not be obtained. Therefore, further research need to use the panel data to solve the problem. What's more, more proxies variables which can proxy the unobserved individual's ability should be considered to test the robustness of the results.

\section{Acknowledgements}

I want to appreciate my tutor's help, he had given me many suggestions which are very helpful for me to finish this article. What's more, I also would like to thank my friends who are also my classmates, they have taught me a lot of useful ideas.

\section{Conflicts of Interest}

The author declares no conflicts of interest regarding the publication of this paper.

\section{References}

[1] Hamilton, B.H. (1997) Returns to Computer Skills and Black-White Wage Differentials. John M Olin School of Business. 
[2] Meng, F.Q. (2014) Urban-Rural Wage Gap under the Multiple Division of the Labor Market. Population and Economy, No. 2, 76-85.

[3] Su, B.W. and Almas, H. (2013) Analysis of the Determinants of Income and Income Gap between Urban and Rural China. China Economic Policy Review, 2, 1-29. https://doi.org/10.1142/S1793969013500027

[4] Xu, F.H. and Zhao, Z. (2014) Study on the Influence of Household Registration System and Enterprise Characteristics on Wage Income Gap. Journal of Renmin University of China, No. 3, 19-28.

[5] Liu, Z.L. and Jin, W.J. (2015) Analysis of the Payroll Premium Effect of Computer Network-Based on CFPS2010 Baseline Survey Data. Industrial Economic Review, No. 1, 67-78.

[6] Chang, J.X. and Zhao, H.T. (2016) Study on the Influence of Ownership on the Wage Gap between Rural Household Labor and Urban Household Labor. China Economic Quarterly, No. 2, 627-646.

[7] Nelson, R.R. and Phelps, E.S. (1966) Investment in Humans, Technology Diffusion, and Economic Growth. The American Economic Review, 56, 69-75.

[8] Benhabib, J. and Spiegel, M.M. (2002) Human Capital and Technology Diffusion. Handbook of Economic Growth, 1, 935-966. https://doi.org/10.1016/S1574-0684(05)01013-0

[9] Demoussis, M. and Giannakopoulos, N. (2006) Facets of the Digital Divide in Europe: Determination and Extent of Internet Use. Economics of Innovation \& New Technology, 15, 235-246. https://doi.org/10.1080/10438590500216016

[10] Chinn, M.D. and Fairlie, R.W. (2010) ICT Use in the Developing World: An Analysis of Differences in Computer and Internet Penetration. Review of International Economics, 18, 153-167. https://doi.org/10.1111/j.1467-9396.2009.00861.x

[11] Goldfarb, A. and Prince, J. (2008) Internet Adoption and Usage Patterns Are Different: Implications for the Digital Divide. Information Economics \& Policy, 20, 2-15. https://doi.org/10.1016/j.infoecopol.2007.05.001

[12] Wunnava, P.V. and Leiter, D.B. (2009) Determinants of Intercountry Internet Diffusion Rates. American Journal of Economics \& Sociology, 68, 413-426. https://doi.org/10.1111/j.1536-7150.2009.00634.x

[13] Chen, Y.Y. and Wu, Y.L. (2008) The Impact of Informatization on the Labor Market: An Estimate of the Rate of Return on Personal Computer Use. China Economic Quarterly, No. 4, 1149-1166.

[14] Bu, M.L., Luo, H.J. and Zhou, G. (2011) The Impact of Internet on Labor Market: An Empirical Study Based on China Household Panel Survey (CFPS) Data. South China Population, No. 5, 1-10.

[15] Li, Y.N. and Xie, Q.Y. (2017) Internet Use and Wage Income Gap: Empirical Analysis Based on CHNS Data. Economic Theory and Business Management, No. 7, 87-100.

[16] Mao, Y.F., Zeng, X.Q. and Hu, W.X. (2018) Can Internet Use Reduce the Gender Wage Gap?-Experience Analysis Based on CFPS Data. Journal of Finance and Economics, No. 7, 33-45.

[17] Krueger, A.B. (1993) How Computers Have Changed the Wage Structure: Evidence from Microdata, 1984-1989. Quarterly Journal of Economics, 108, 33-60. https://doi.org/10.2307/2118494

[18] Dinardo, J.E. and Pischke, J. (1997) The Returns to Computer Use Revisited: Have Pencils Changed the Wage Structure Too? Quarterly Journal of Economics, 112, 
291-303. https://doi.org/10.1162/003355397555190

[19] Bell, B.D. (1996) Skill-Biased Technical Change and Wages: Evidence from a Longitudinal Data Set. Nuffield College Press, Oxford.

[20] Lee, S.H. and Kim, J. (2004) Has the Internet Changed the Wage Structure Too? Labour Economics, 11, 119-127. https://doi.org/10.1016/S0927-5371(03)00052-6

[21] Navarro, L. (2010) The Impact of Internet Use on Individual Earnings in Latin America. Development Research Working Paper Series.

[22] Lian, Y.J. and Liao, J.P. (2017) How to Check the Difference between Groups after Group Regression? Journal of Zhengzhou Institute of Aeronautical Industry Management, No. 6, 97-109. 